\title{
Is renal medullary carcinoma the seventh nephropathy in sickle cell disease? A multi-center Nigerian survey.
}

Madu Anazoeze ${ }^{1}$, Galadincci Najibah ${ }^{2}$, Umar Garba ${ }^{3}$, Abdulahi Shehu ${ }^{4}$, Fowodu Florence ${ }^{5}$, Hassan Abdulaziz ${ }^{6}$, Inyama Marcus ${ }^{7}$, Akinpelu Oluwaseun ${ }^{8}$, Nwagha Theresa ${ }^{9}$, Ibegbulam Obike ${ }^{9}$, Ocheni Sunday ${ }^{9}$, Emodi Ifeoma ${ }^{9}$, Ikefuna Anthony ${ }^{9}$, Chukwu Barth ${ }^{9}$, Okocha Chide ${ }^{10}$, Orkuma Joseph ${ }^{3}$, Iheanacho Malachy ${ }^{3}$,

Korubo Kaladada ${ }^{11}$, Anike Uche ${ }^{9}$, Agu Kingsley ${ }^{9}$, Nonyelu Charles ${ }^{9}$, Ugwu Angela ${ }^{9}$, Duru Augustin ${ }^{9}$, Anigbo Chikwudi ${ }^{9}$, Eze Alozie ${ }^{3}$, Ololo Uchenna ${ }^{9}$, Omoti Caroline ${ }^{12}$, Agwu Obineche ${ }^{3}$, Okpala Iheanyi ${ }^{9}$

1. University of Nigeria, Haematology \& Immunology; university of Nigeria Teaching Hospital, Haematology \& Immunology

2. Aminu Kano Teaching Hospital, Haematology

3. Federal Medical Center, Haematology

4. Aminu Kano Teaching Hospital, Paediatrics

5. University College Hospital, Ibadan, Department of Haematology

6. Ahmadu Bello University Teaching Hospital, Haematology

7. University of Calabar Teaching Hospital, Calabar, Department of Haematology

8. Ladoke Akintola University of Technology, Haematology

9. University of Nigeria Teaching Hospital, Enugu

10. Nnamdi Azikiwe University, Haematology

11. University of Port Harcourt Teaching Hospital, Nigeria, Department of Haematology

12. University of Benin Teaching Hospital, Haematology

\begin{abstract}
Introduction: Previous studies had enlisted renal medullary carcinoma (RMC) as the seventh nephropathy in sickle cell disease (SCD). Clinical experience has contradicted this claim and this study is targeted at refuting or supporting this assumption.

Objective: To estimate the prevalence of RMC and describe other renal complications in SCD.

Materials and methods: 14 physicians (haematologists and urologists) in 11 tertiary institutions across the country were collated from patients' case notes and hospital SCD registers.

Results: Of the 3,596 registered sickle patients, $2(0.056 \%)$ had been diagnosed with RMC over a ten year period, thereby giving an estimated prevalence rate of 5.6 per 100,000. The most common renal complication reported by the attending physicians was chronic kidney disease (CKD). The frequency of routine renal screening for SCD patients varied widely between centres - most were done at diagnosis, annually or bi-annually.

Conclusion: The ten year prevalence of RMC in Nigerian SCD patients was determined to be 5.6 (estimated incidence of 0.56 ). RMC is not more common in SCD patients and therefore cannot be regarded as a "Seventh Sickle nephropathy". Most of the managing physicians reported that the commonest nephropathy observed in their SCD patients was chronic kidney disease.
\end{abstract}

Keywords: Renal medullary carcinoma, seventh nephropathy, sickle cell disease, Nigerian survey.

DOI: http://dx.doi.org/10.4314/ahs.v16i2.17

Cite as: Anazoeze M, Najibah G, Garba U, Shehu A, Florence F, Abdulaziz H, et al. Is renal medullary carcinoma the seventh nephropathy in sickle cell disease? A multi-center Nigerian survey. Afri Health Sci 2016;16(2): 490-496. http:/ / dx.doi.org/10.4314/ ahs.v16i2.17

\section{Corresponding author: \\ Madu Anazoeze, University of Nigeria, haematology \& Immunology; university of nigeria teaching hospital, haenatology \& Immunology Email: anazoeze.madu@unn.edu.ng}

\section{Introduction}

Sickle cell disease (SCD) is caused by an inherited point mutation causing replacement of the hydrophilic polar amino acid glutamate by a less polar hydrophobic amino acid, valine at the 6th position of the beta globin chain. The prevalence of carriers state - sickle cell trait (haemoglobin AS - HbAS) ranges between 10 and 40\% across 
equatorial Africa, decreases to $1-2 \%$ in North Africa, and to less than $1 \%$ in parts of Africa south of river Zambesi 1. The incidence of SCD at birth is determined by the prevalence of carriers in the population. SCD has profound public health implications in Africa as it contributes about $5 \%$ to under-five mortality, with up to $16 \%$ occurring in West Africa. Globally, about 300,000 children are born every year with $\mathrm{SCD}^{2}$ and Nigeria accounts for one-third of this population of people living with sickle cell ${ }^{1}$.

In 1974, Berman described 6 nephropathies that occur in people who have either SCD or sickle cell trait which were attributed to vascular stagnation, reduced oxygen pressure and renal medullary hypertonicity ${ }^{3}$.The 6 nephropathies were gross haematuria, papillary necrosis, nephrotic syndrome, renal infarction, hyposthenuria and pyelonephritis. Previous reports had described RMC as a rare tumor of kidney that notably occurred in young African American patients with $\mathrm{SCD}^{4}$ or sickle cell trait, which they proposed to call the "seventh sickle cell nephropathy ${ }^{\prime \prime, 6}$. Renal medullary carcinoma as a tumor is rare, very aggressive (with death often occurring within one year of diagnosis) and resistant to immunotherapy and chemotherapy. The age incidence of renal medullary carcinoma ranges from 11 to 39 years, with male preponderance $(3: 1)$ in patients under the age of 25 years ${ }^{5}$. The relatively young age of patients with this carcinoma prompted the search for genetic factors likely to be involved in its pathogenesis. Cytogenetics revealed monosomy 11 in 4 out of 6 successfully karyotyped tumors ${ }^{7}$. Studies that are more recent have shown the loss or alteration of SMARCB1/INI1 gene with increased cyclinD1 expression as a possible molecular pathogenetic causative pathway $^{8}$. However, all the patients had sickle cell trait and, coincidentally, the beta globin gene locus is in the short arm of chromosome 11. A possible relationship might be that chromosome 11 is involved in the development of renal medullary carcinoma.

This kidney tumour may be diagnosed by ultrasonography, excretory urography or computed tomography ${ }^{5,9}$.It usually involves the central portion of kidney and ultrasonography shows a centrally located solid space-occupying lesion of kidney with heterogeneous echogenicity. It may not be well visualized on excretory urography which occasionally shows evidence of a kidney mass and distor- tion of the adjacent calyx. Computed tomography (CT) reveals infiltrative and indistinct masses that usually arise in the central region of the kidney, with invasion of the renal sinus fat. CT contrast enhancement shows the lesion in all patients, and retroperitoneal lymphadenopathy ${ }^{9}$. Filling defects in the pelvi-calyceal system may be seen on a retrograde pyelography. Ancillary investigations include ureteroscopy (may reveal a sessile mass lesion in the pelvi-calyceal system), angiography (may show hypovascular tumour) and cytology of the urine which may detect malignant cells. Nephrectomy for non-metastasized tumours, with removal of the retroperitoneal nodes, is usually the treatment of choice. Removal of the retroperitoneal lymph nodes is suggested in some cases but is not standard in renal cell carcinoma, however it is recommended in aggressive tumors such as renal medullary carcinoma. It has not shown to improve survival but is helpful for staging ${ }^{10}$. However, due to the high proliferation rate of this carcinoma and its tendency to metastasize early, most patients present after the tumour had spread; and are treated with chemotherapy ${ }^{11}$.

Renal medullary carcinoma has long been proposed to be one of the complications of SCD. Nigeria with a large population of patients living with SCD (1-2 million) is a naturally vantage location to evaluate the postulated association between this haemoglobinopathy and renal medullary carcinoma. The aim of this study was to determine the prevalence of renal cell carcinoma among SCD patients in Nigeria, as well as describe the renal complications found in this patient population.

\section{Materials and methods}

The study was a hospital-based retrospective descriptive analysis obtained from hospital records across Nigerian. The survey was done using a 7-item pre-validated (prevalidation was done with five Physicians who filled the draft questionnaire and were not included in the study) questionnaire was sent to 22 Physicians (Haematologists and Urologists) in 17 tertiary health institutions across the different geo-political zones in Nigeria. The selection of the centers, was non-randomized and questionnaires were sent to all centers which the authors had correspondence with. Information included; speciality, number of registered patients, data duration, number of patients diagnosed with RMC, frequency and modalities of renal screening in SCD patients as well as the most common 
renal complication of SCD recorded in the center. Other information obtained included the types of nephropathy encountered in SCD patients seen across the country, and the tests for detecting sickle nephropathy recommended by the physicians.

Data on a total of 3,596 SCD patients receiving care in 11 tertiary healthcare institutions across Nigeria who had responded, was collected. These tertiary health institutions are located in different geographical expanse of the country and receive patients across various states and counties, a population ranging from 1-3 million persons. The various durations over which the data was captured in the participating centers were also obtained and the median duration was estimated. The data was used to obtain rates and descriptive data are presented in tables. The prevalence of renal medullary carcinoma was determined using IBM SPSS Statistics for windows version 19.0 package (IBM Corporation, Armonk, NY, USA). Ethical approval was obtained from the health research and ethics committee of the participating centers.

\section{Results}

The respondents to this survey involved included 14 $(64 \%)$ physicians in $11(65 \%)$ tertiary heath institutions across the various geographical populations across the country. The 14 physicians who provided data from their centers included $11(78.6 \%)$ haematologists, 1(7.1\%) urologist and $2(14.3 \%)$ pediatricians. Duration over which the data was collected varied from 6 to 16 years in the different centers, with a median duration of 10 years and mean of 10.1 years. Renal medullary carcinoma was reported in 2 out of the 3,596 patients, making the 10 year prevalence rate $0.056 \%$. Both cases were from the same center (Aminu Kano Teaching Hospital Kano), which also had the largest pool of SCD patients $-1,800$ registered patients. One of the patients was a 32 year old house wife who had completed secondary education, and her husband was a junior cadre government employee, while the other was 28 year old single male patient. Both patients were homozygous $\mathrm{S}$ and diagnosis was based on CT as well as renal biopsy histology. The average number of SCD patients registered in each of the 14 tertiary hospital units under study, ranged from 20 - 1500, with a median of 128 patients. The number of SCD patients registered in each center is shown in table 1. 
Table 1. Patient distribution and duration of data collection among the participating centers.

\begin{tabular}{|c|c|c|c|}
\hline Institution & & $\begin{array}{l}\text { Numbers of registered } \\
\text { patients }(n=3,596)\end{array}$ & $\begin{array}{l}\text { Duration of data } \\
\text { collected (years) }\end{array}$ \\
\hline $\begin{array}{l}\text { Aminu Kano Teaching Hospital, } \\
\text { Kano (Adult clinic) }\end{array}$ & & 1500 (41.7\%) & $7(5.3 \%)$ \\
\hline $\begin{array}{l}\text { University of Nigeria Teaching } \\
\text { Hospital, Enugu (Paediatrics clinic) }\end{array}$ & & 350 (9.7\%) & $10(7.7 \%)$ \\
\hline $\begin{array}{l}\text { Aminu Kano Teaching Hospital, } \\
\text { Kano (Urology Clinic) }\end{array}$ & & $300(8.4 \%)$ & $10(7.7 \%)$ \\
\hline $\begin{array}{l}\text { Federal Medical Center, Birinin- } \\
\text { Kebbi, Kebbi State (Adult clinic) }\end{array}$ & & $300(8.4 \%)$ & $6(4.6 \%)$ \\
\hline $\begin{array}{l}\text { University College Hospital, Ibadan } \\
\text { (Adult clinic) }\end{array}$ & & $300(8.4 \%)$ & $6(4.6 \%)$ \\
\hline $\begin{array}{l}\text { University of Calabar Teaching } \\
\text { Hospital (Adult clinic) }\end{array}$ & & 215 (5.9\%) & $10(7.7 \%)$ \\
\hline $\begin{array}{l}\text { Ahmadu Bello University Teaching } \\
\text { Hospital, Zaria, Kaduna State(Adult } \\
\text { clinic) }\end{array}$ & & $160(4.5 \%)$ & $10(7.7 \%)$ \\
\hline $\begin{array}{l}\text { University of Nigeria Teaching } \\
\text { Hospital, Enugu(Adult clinic) }\end{array}$ & & $156(4.3 \%)$ & $16(12.4 \%)$ \\
\hline $\begin{array}{l}\text { NnamdiAzikiwe University Teaching } \\
\text { Hospital Nnewi (Adult clinic) }\end{array}$ & & $100(2.8 \%)$ & $10(7.7 \%)$ \\
\hline $\begin{array}{l}\text { Benue State University Teaching, } \\
\text { Makurdi (Adult clinic) }\end{array}$ & & $58(1.7 \%)$ & $14(10.8 \%)$ \\
\hline $\begin{array}{l}\text { University of Benin Teaching } \\
\text { Hospital, Edo State (Adult clinic) }\end{array}$ & & $56(1.6 \%)$ & $10(7.7 \%)$ \\
\hline $\begin{array}{l}\text { NnamdiAzikiwe University Teaching } \\
\text { Hospital Nnewi (Paediatrics clinic) }\end{array}$ & & 55 (1.5\%) & $7(5.3 \%)$ \\
\hline $\begin{array}{l}\text { Federal Medical Center, Owerri, } \\
\text { Imo State (Adult clinic) }\end{array}$ & & $26(0.7 \%)$ & $8(6.2 \%)$ \\
\hline $\begin{array}{l}\text { University of Port Harcourt } \\
\text { Teaching Hospital (Adult clinic) }\end{array}$ & & $20(0.4 \%)$ & $6(4.6 \%)$ \\
\hline \multirow[t]{3}{*}{ Total } & $N(100 \%)$ & 3596 (100\%) & $130(100 \%)$ \\
\hline & Mean & 257 & \\
\hline & Median & 128 & \\
\hline
\end{tabular}


All the respondents included urinalysis as one of the routine tests used in screening for sickle nephropathy, 12/14 $(85.7 \%)$ routinely requested renal function test, and 8/14 $(57.1 \%)$ did routine abdominal ultrasonography for renal evaluation. None of the centers under study used computerized tomography scan (CT scan) for screening or investigating renal disease routinely. The frequency of renal screening and evaluation varied widely, from once (at diagnosis) to quarterly (once every 3 months). In 3 of the centers screening was done at diagnosis only, screening was done annually in 3 centers and 6-monthly inter- vals in 4. This is shown in table 2.The commonest renal complications of sickle cell disease observed are shown in table 2 , the commonest nephropathy observed by the physicians in the participating centers was chronic kidney disease $(42.9 \%$ or $6 / 14)$ and proteinuria in $28.6 \%$ (4/14). Chronic kidney disease is defined as a diminished renal function with a reduction in glomerular filtration rate with or without kidney damage, while proteinuria refers to excessive protein excretion in urine above normal for age and sex. Other less frequent complications were papillary necrosis, nephrotic syndrome, renal stones and recurrent urinary tract infection.

Table 2. Frequency of renal screening and renal complications observed in sickle cell disease.

\begin{tabular}{llll}
\hline Variable & & Frequency $(\mathbf{n}=15)$ & Percentage \\
\hline Routine renal screening & At diagnosis & 4 & 26.7 \\
& Seldom & 2 & 13.3 \\
& 3 monthly & 2 & 13.3 \\
& 6 monthly & 4 & 26.7 \\
& Annually & 3 & 20.0 \\
& & & \\
Most common renal & & Frequency $(\mathbf{n}=14)$ & \\
complication & & & 42.9 \\
& CKD & 6 & 28.6 \\
& Proteinuria & 4 & 14.3 \\
& Nephrotic syndrome & 2 & 7.1 \\
& Recurrent UTI & 1 & 7.1 \\
\hline
\end{tabular}

\section{Discussion}

The 10 year prevalence of $0.056 \%$ observed in this study is comparable to the incidence of this malignancy in the general population; which is 3.9 per $100,000^{12}$. The study by Davis et $\mathrm{al}^{2}$ found a higher incidence of this malignancy in individuals with sickle cell trait (HbAS), but not in homozygous HbSS people. However this study implicated the sickling of red cells in the pathogenesis of this malignancy (as observed in the histology of the diseased tissue) a hypothesis which if correct, would render homozygous $\mathrm{S}$ individuals equally vulnerable. No study has demonstrated that kidney cancers are more prevalent in HbSS persons other than Baron et $\mathrm{al}^{13}$ who found a 16.7 fold excess in HbSS individuals, in a forty year retrospective study. However, the data was not expressed as prevalence rates; making it difficult to compare with the rate in the general population. Also, Barons study was targeted at African Americans in the United States of America, diagnosed with RCC, and not on sickle cell patients, primarily. The effect of environmental exposure as well as occupational hazards leading to this predisposition has to be further evaluated. 
The incidence of cancers of the kidney and renal pelvis in African Americans has been estimated to be 23.3 in males and 12.1 in females per 100,000(equivalent to 0.23 and 0.12 per 1000 respectively) ${ }^{14}$. This is higher than the estimated incidence of 5.6 per 100,000 observed in this study. Though this rate includes all malignancies of the kidneys and renal pelvis in the normal population, it is known that RMC represents less than $1 \%$ of the cancers of the kidney ${ }^{11,15}$. Further more in the study by Davies et al, $62 \%$ of the patients $(34 / 55)$ with kidney cancer were found to have RMC. Therefore from the observed prevalence in this study, an estimated total prevalence of 16.8 per 100,000 can be derived for cancers of the kidney in HbSS individuals. This invariably suggests that HbSS patients do not have a higher tendency to develop RMC. The term "Seventh Nephropathy" in sickle cell therefore cannot be correctly ascribed to renal medullary carcino$\mathrm{ma}$, as it has not been shown to have a higher incidence in people living with sickle cell disease.

The participants in this study were selected in a consecutive and non-randomized manner, involving all physicians who obliged. This method of sampling though not optimal with regards to the bias, however provides some valuable information and also reveals the paucity of documentation with regards to patients records in developing countries. The overall response rate amongst the centers invited to participate was approximately $65 \%$. Either the result obtained therefore may be bloated or less than the real figures, however some deductions can be made from the results so far obtained.

The majority of physicians included in this survey reported that chronic kidney disease was the most common renal complication among their HbSS patients, followed by proteinuria and nephrotic syndrome. Previous studies had reported proteinuria (albuminuria) as the most common renal complication in SCD, with chronic renal failure (CRF) in $20 \%$ of the patients ${ }^{16,17}$. This may be in the circumstance of overt renal failure, though micro-albuminuria may be discovered in clinics where this is routinely screened, thus explaining its lower frequency. The finding from this study that chronic renal disease is the commonest renal complication of SCD is consistent with previous observations ${ }^{17}$. This further supports the routine screening for micro-albminuria in sickle cell patients as a means of preventing chronic kidney disease. HbSS patients have impaired immunity leading to recurrent urinary tract in- fection, especially in children who may be asymptomatic. Papillary necrosis has been reported in $30-40 \%$ of $\mathrm{HbSS}$ individuals, although this complication could be asymptomatic in up to $62 \%$ of those affected ${ }^{18}$. Only $7.1 \%$ of the physicians who conducted this study reported renal papillary necrosis as a common finding. However, it must be noted that a greater percentage of HbSS patients actually have asymptomatic haematuria that can only be detected by serial urinalysis or microscopy.

\section{Conclusion}

The 10 year prevalence of renal medullary carcinoma in sickle cell disease patients was found to $0.056 \%$. This is comparable to the incidence of cancers of the kidney in the overall population, and suggests that sickle cell disease patients do not have a higher tendency to develop renal medullary carcinoma. The term "Seventh Nephropathy of Sickle cell" with regards to RMC, is inappropriate as HbSS does not confer a higher predisposition to the occurrence of this malignancy.

Chronic kidney disease (CKD) was also found to be the commonest renal complication of sickle cell disease found in people living with sickle cell disease.

\section{Disclosures}

None

\section{Conflict of interest}

There was no conflict of interest amongst the authors of this manuscript.

\section{References}

1. Okpala I. Epidemiology, genetics and pathophysiology of SCD. In: Okpala I, editor. Practical management of haemoglobinopathies.Oxford: Blackwell publishing; 2004. p. 20-5.

2. Anie KA, Egunjobi FE, Akinyanju OO. Psychosocial impact of sickle cell disorder: perspectives from a Nigerian setting. Global Health 2010;6:2. doi:10.1186/17448603-6-2

3. Berman I B. Sickle cell nephropathy. JAMA 1974;228:1279.

4. Liu Q, Galli S, Srinivasan R, Linehan WM, Tsokos M, Merino MJ. Renal medullary carcinoma: molecular, immunohistochemistry, and morphologic correlation. Am J Surg Pathol 2013;37(3):368-74. doi: 10.1097/ PAS.0b013e3182770406. 
5. Davis CJ, Jr., Mostofi FK, Sesterhenn IA. Renal medullary carcinoma. The seventh sickle cell nephropathy. $A m$ J Surg Pathol 1995 January;19(1):1-11.

6. Luthra M, Bayne F. The seventh sickle cell nephropathy. Intern Med 2010;49(23):2641. http://doi.org/10.2169/internalmedicine.49.4479

7. Wesche WA, Wilimas J, Khare V, Parham DM. Renal medullary carcinoma: a potential sickle cell nephropathy of children and adolescents. Pediatr Pathol Lab Med 1998 ;18(1):97-113.

8. Calderaro J, Moroch J, Pierron G, Pedeutour F, Grison C, Maille P, Soyeux P, de la Taille A, Couturier J, Vieillefond A, Rousselet MC, Delattre O, Allory Y. SMARCB1/ INI1 inactivation in renal medullary carcinoma. Histopathology 2012 ;61(3):428-35. . doi: 10.1111/j.13652559.2012.04228.x.

9. Davidson AJ, Choyke PL, Hartman DS, Davis CJ, Jr. Renal medullary carcinoma associated with sickle cell trait: radiologic findings. Radiology 1995 April;195(1):83-5. http://dx.doi.org/10.1148/radiology.195.1.7892499

10. Geller R, Hemal S, Manny T. Lymphadenectomy for renal cell carcinoma and urothelial carcinoma of the upper urinary tract: analysis of evidence in the minimally invasive era. Minerva Med 2013 June;104(3):261-72.

11. Gupta R, Billis A, Shah RB, Moch H, Osunkoya AO, Jochum W, Hes O, Bacchi CE, de Castro MG, Hansel DE, Zhou M, Vankalakunti M, Salles PG, Cabrera RA, Gown AM, Amin MB. Carcinoma of the collecting ducts of Bellini and renal medullary carcinoma: clinicopatho- logic analysis of 52 cases of rare aggressive subtypes of renal cell carcinoma with a focus on their interrelationship. Am J Surg Pathol 2012 September;36(9):1265-78. doi: 10.1097/PAS.0b013e3182635954

12. Ferlay J, Shin HR, Bray F, Forman D, Mathers C, Parkin DM. Estimates of worldwide burden of cancer in 2008: GLOBOCAN 2008. Int J Cancer 2010 December 15;127(12):2893-917. doi: 10.1002/ijc.25516

13. Baron BW, Mick R, Baron JM. Hematuria in sickle cell anemia--not always benign: evidence for excess frequency of sickle cell anemia in African Americans with renal cell carcinoma. Acta Haematol 1994;92(3):119-22.

14. American Cancer Society. Cancer Facts and Figures 2013. 43. 2013. Atlanta: American Cancer Society.

15. Maroja Silvino MC, Venchiarutti Moniz CM, Munhoz Piotto GH, Siqueira S, Galapo KA, Dzik C. Renal medullary carcinoma response to chemotherapy: a referral center experience in Brazil. Rare Tumors 2013;5(3):e44. doi: 10.4081/rt.2013.e44.

16. Guasch A, Navarrete J, Nass K, Zayas CF. Glomerular involvement in adults with sickle cell hemoglobinopathies: Prevalence and clinical correlates of progressive renal failure. J Am Soc Nephrol 2006 August;17(8):2228-35. doi:10.1681/ASN.2002010084

17. Lopez RK, Ricard Andres MP. Kidney abnormalities in sickle cell disease. Nefrologia 2011;31(5):591-601. doi: 10.3265/Nefrologia.pre2011.Feb.10737

18. Pandya KK, Koshy M, Brown N, Presman D. Renal papillary necrosis in sickle cell hemoglobinopathies. J Urol 1976 May;115(5):497-501. 